\title{
The Photosensitizing Activity of Haematoporphyrin on Mollicutes
}

\author{
By GIULIO BERTOLONI, ' * ALESSANDRA VIEL, ' ANNA GROSSATO' \\ AND GIULIO JORI?
}

Istituto di Microbiologia ${ }^{1}$ and Dipartimento di Biologia², Unicersità di Padora, 35 I00 Padora, Italy

(Received 17 December 1984; revised 2 May 1985)

\begin{abstract}
The photosensitizing activity of haematoporphyrin (HP) on Mycoplasma hominis and Acholeplasma laidlawii was studied as a function of the phase of growth and the amount of sterols in the cell membrane. Less HP was bound to cells when the membrane had a high sterol content. Both strains in the exponential but not in the stationary phase of growth were sensitive to $\mathrm{HP}$ treatment (above $1 \mu \mathrm{g} \mathrm{ml}^{-1}$ ) in the dark. Visible light irradiation of $\mathrm{HP}$-loaded cells caused in all cases a decrease of cell survival, with concomitant changes in the pattern of membrane proteins that suggested protein-protein cross-linking, and the appearance of ultrastructural alterations (rounded and lysed cells); the photosensitivity was indirectly related to the sterol content of the cell membrane. On the whole, our findings suggest that the cell membrane is a major target for HP photosensitization of mycoplasma cells.
\end{abstract}

\section{INTRODUCTION}

Cell damage as a consequence of visible light irradiation of porphyrin-sensitized cells is a welldocumented phenomenon (for review see Jori \& Spikes, 1984). Several effects of photoactivated porphyrins on mammalian cells have been observed, including cross-linking of membrane proteins, inhibition of the transport of essential metabolites, inactivation of membrane enzymes and increased uptake of porphyrin (Moan \& Christensen, 1981): however, the damage directly responsible for cell death is still largely unknown.

Previous investigations on the mechanisms of the photosensitizing action of porphyrin in micro-organisms suggested that the cytoplasmic membrane was the most important target (Bertoloni et al., 1982, 1984). These results induced us to extend our studies to the photosensitizing action of haematoporphyrin (HP) on members of the class Mollicutes. The ease with which their membrane can be isolated and the ability to introduce controlled variations in its composition have made mycoplasma membranes effective and popular tools in biomembrane research (Razin, 1978). In particular we investigated the photosensitizing activity of HP on Mycoplasma hominis and Acholeplasma laidlawii, characterized by cell membranes with high and low cholesterol content, respectively.

\section{METHODS}

Orgamisms. Micoplasma hominis strain PG 21 was kindly provided by $\mathrm{Dr}$ M. F. Barile. Food and Drug Administration, Bethesda, Md, USA, and Acholeplasma laidlawii strain NCTC 10116 was supplied by the National Collection of Type Cultures, Colindale, London. UK.

Grouth media and culture' conditions. M. hominis, and A. laidlawii designated as $+\mathrm{S}$, were grown in Tryptic Soy Broth (Difco) supplemented with $20^{\circ}{ }_{0}(\mathrm{v} / \mathrm{v})$ horse serum, $2 \cdot 5^{\circ} \mathrm{o}(\mathrm{w} / \mathrm{v})$ yeast extract $(\mathrm{Difco})$ and 500 units penicillin $\mathrm{G} \mathrm{ml}^{-1}$, incubated at $37 \mathrm{C}$ under aerobic conditions. The same medium without horse serum was used for growing A. laidlawii designated as $-\mathrm{S}$. For the cell survival assay the complete medium containing purified agar $\left(1 \cdot 2^{\circ}{ }_{0}, \mathrm{w} / \mathrm{v}\right)$ (Difco) was used.

Abbreviation: HP, haematoporphyrin. 


Exponential
Supernatant discarded

Fig. 1. Summary of experimental procedure.

To determine the amount of cholesterol in the organisms, the total lipids were extracted (Bligh \& Dyer, 1959), and the amount of cholesterol was determined by the method of Rudel \& Morris (1973).

Cell survival assay. Unirradiated and irradiated cell samples were diluted 10-fold serially in phosphate-buffered

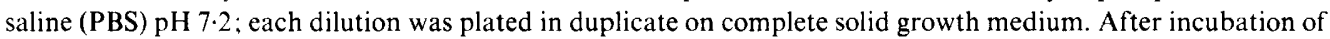
the plates at $37^{\circ} \mathrm{C}$ for $2-5 \mathrm{~d}$, the number of c.f.u. $\mathrm{ml}^{-1}$ was counted with the aid of a light microscope.

HP treatment and irradiation procedure. Cells from cultures in the exponential and stationary phases of growth were harvested by centrifugation at $15000 \mathrm{~g}$ for $30 \mathrm{~min}$ at $4{ }^{\circ} \mathrm{C}$. The sedimented cells were resuspended in PBS, washed twice in $10 \mathrm{ml}$ PBS by magnetic stirring for $30 \mathrm{~min}$, and then centrifuged at $600 \mathrm{~g}$ for $10 \mathrm{~min}$ to remove clumped cells. The cell suspensions used in all experiments had an $\mathrm{OD}_{650}$ of 0.07 . HP, obtained from Porphyrin Products (Logan, Utah) was dissolved in $0 \cdot 1 \mathrm{M}-\mathrm{NaOH}$ and diluted to the desired concentration by adding PBS. HP solutions in PBS were stable for at least one week if kept in the dark at $4{ }^{\circ} \mathrm{C}$. All irradiation experiments were performed using four $250 \mathrm{~W}$ tungsten lamps (Osram), whose light was focused on a Pyrex test tube containing the system to be irradiated $(10 \mathrm{ml})$. The fluence at the level of the test tube was about $18 \mathrm{~cd} \mathrm{~m}^{-2}$. The cell suspensions were aerated and maintained at $37^{\circ} \mathrm{C}$. The irradiated and unirradiated systems were prepared by adding a suitable volume of the HP solutions to cell suspensions, the final dye concentration being in the range $0 \cdot 01-100 \mu \mathrm{g} \mathrm{ml}^{-1}$. At intervals prior to and during irradiation, samples were taken from suspensions for assay (Fig. 1). Previous control experiments had shown that, under the experimental conditions described above, cells were unaffected by $30 \mathrm{~min}$ illumination in the absence of added HP.

Electron microscopy. Cell suspensions obtained and treated as described in Fig. 1 were fixed in glutaraldehyde, post-fixed in osmium tetroxide and then embedded in Dow epoxy resin as described previously (Meloni et al., 1980). Thin sections were stained with uranyl acetate and lead citrate (Reynolds, 1963) and then examined in a Hitachi HS9 electron microscope.

Dark and light interaction between haematoporphyrin and cells. Samples of washed cell suspension ( $\left.\mathrm{OD}_{650} 0 \cdot 07\right)$ were incubated with known amounts of HP for $30 \mathrm{~min}$ at room temperature and processed as indicated in Fig. 1. The amount of cell-bound HP was estimated by a spectrophotofluorimetric procedure involving the washing of HP-treated cells with PBS in order to remove unbound porphyrin and the subsequent exposure of cells to $2 \%$ ( $w / v)$ SDS (Jori et al., 1979); in this way, HP is incorporated in a monomeric form into SDS micelles. The spectra were recorded using a Perkin Elmer MPF4 apparatus: the sample solutions were excited at $400 \mathrm{~nm}$ and the fluorescence emission was recorded in the $550-750 \mathrm{~nm}$ range. The integrated area of the spectra was converted into values of HP concentration by interpolation with a standard plot.

Electrophoresis. Changes in the pattern of membrane proteins were detected after exposure of cells to HP and/or light, as described above. The cell membranes were obtained by osmotic and digitonin lysis for $A$. laidlawii and $M$. 


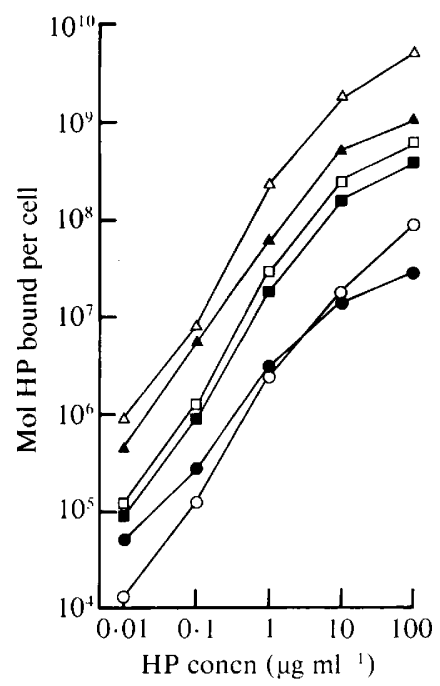

Fig. 2. Effect of HP concentration in the incubation medium on the amount of porphyrin bound by cells of $M$. hominis $(\boldsymbol{O}, \mathcal{O}), \boldsymbol{A}$. laidlawii $+\mathrm{S}(\boldsymbol{\square}, \square)$ and $\boldsymbol{A}$. laidlawii $-\mathbf{S}(\boldsymbol{\Delta}, \Delta)$ in the exponential (filled symbols) and stationary (open symbols) phases of growth. The incubation was performed at room temperature for $30 \mathrm{~min}$ and the cell-bound HP was estimated by a spectrophotofluorimetric procedure.

hominis respectively (Razin, 1963; Rottem \& Razin, 1972). The total protein content was determined by the method of Lowry. The membrane preparations were resuspended (at a final protein concentration of $5 \mu \mathrm{g} \mathrm{ml}^{-1}$ ) in buffer containing $0.625 \mathrm{M}-\mathrm{Tris} / \mathrm{HCl} \mathrm{pH} 6 \cdot 8,10 \%(\mathrm{v} / \mathrm{v})$ glycerol, $10 \%(\mathrm{v} / \mathrm{v}) 2$-mercaptoethanol, $1 \%(\mathrm{w} / \mathrm{v})$ SDS and $0.01 \%(\mathrm{w} / \mathrm{v})$ bromophenol blue, and the samples were boiled for $2 \mathrm{~min}$ prior to slab gel electrophoresis (Daniels \& Meddins, 1973). The gel dimensions were $20 \times 15 \times 0.15 \mathrm{~cm}$ and the stacking and separation gels were $4.5 \%$ and $7.5 \%$ polyacrylamide, respectively. The migrations were carried out in $50 \mathrm{~mm}$-Tris $/ 383 \mathrm{~mm}$-glycine buffer ( $\mathrm{pH} 8 \cdot 3$ ) containing $0.1 \%(\mathrm{w} / \mathrm{v})$ SDS and $0.1 \%(\mathrm{v} / \mathrm{v}) 2$-mercaptoethanol, at $70 \mathrm{~V}$, at room temperature overnight. Gels were stained for $30 \mathrm{~min}$ with Coomassie Brilliant Blue $(0.07 \%$ in methanol/glacial acetic acid/water, $5: 1: 1$, by vol.) and then destained with $7 \cdot 5 \%(\mathrm{v} / \mathrm{v})$ glacial acetic acid. The molecular weight of proteins was estimated on the basis of the migration of bovine serum albumin (mol. wt 68000) and ovalbumin (43000).

\section{RESULTS}

HP appeared to have an appreciable affinity for the cells of $M$. hominis and $A$. laidlawii (Fig. 2): the amount of the cell-bound HP increased with increasing HP concentration in the incubation medium, at least within the range $0.01-100 \mu \mathrm{g} \mathrm{m}^{-1}$. For both strains the uptake of HP was very similar in the exponential and stationary phases of growth. The extent of HPbinding decreased in the sequence $A$. laidlawii $-\mathrm{S}, A$. laidlawii $+\mathrm{S}, M$. hominis.

Survival curves of mycoplasma cells after incubation in the dark $(90 \mathrm{~min})$ with HP concentrations ranging between 0.01 and $100 \mu \mathrm{g} \mathrm{ml}^{-1}$ are shown in Fig. 3. The curves obtained for exponential phase cells of $M$. hominis and $A$. laidlawii $+\mathrm{S}$ were similar, while $A$. laidlawii $-\mathrm{S}$ appeared to be more resistant to HP. Cells of each strain in the stationary phase of growth were unaffected by exposure to the above-mentioned HP concentrations.

All studies of photosensitized cell inactivation were performed in the presence of $0 \cdot 1 \mu \mathrm{g} \mathrm{HP} \mathrm{ml} l^{-1}$, since this concentration had no effect on cell survival in the dark. Control experiments showed that in the absence of added HP cells were insensitive to visible light even after $30 \mathrm{~min}$ illumination.

Both strains were sensitive to the photodynamic action of HP (Fig. 4). While M. hominis and A. laidlawii $+\mathrm{S}$ gave plots with an initial shoulder, $A$. laidlawii-S showed no initial lag phase and was somewhat more resistant to photosensitization. 


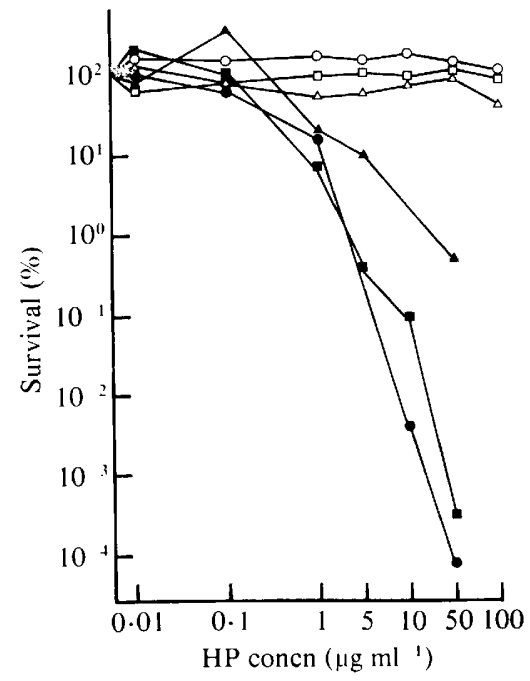

Fig. 3

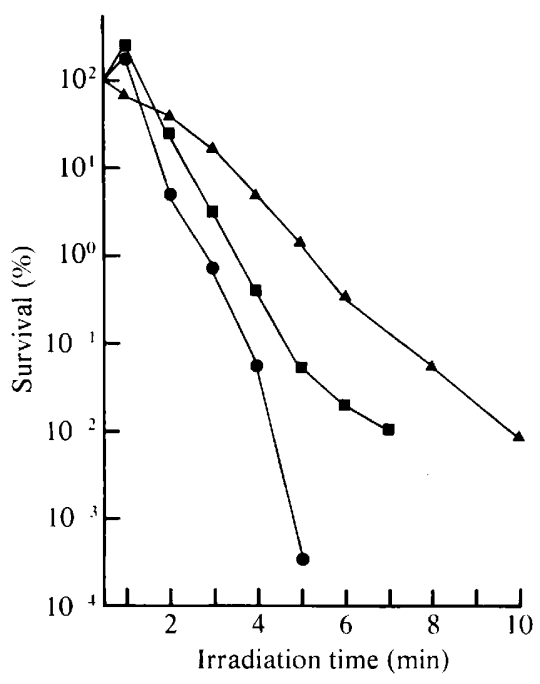

Fig. 4

Fig. 3. Survival of mycoplasma cells in the exponential (filled symbols) and stationary (open symbols) phases of growth after incubation with HP for $90 \mathrm{~min}$ in the dark. The initial cell concentrations [log (c.f.u. $\mathrm{ml}^{-1}$ )] were 7 for $M$. hominis and 6 for $A$. laidlawii ( $+\mathrm{S}$ and $-\mathrm{S}$ ). Each point represents the mean of three independent experiments performed in duplicate. The largest standard error obtained [log (c.f.u. $\mathrm{ml}^{-1}$ )] was $0 \cdot 18, \boldsymbol{O}, \mathrm{O}, M$. hominis; $\mathbf{\square}, \square$, A. laidlawii $+\mathrm{S}, \boldsymbol{\Delta}, \Delta, A$. laidlawii $-\mathrm{S}$.

Fig. 4. Time-dependence of cell survival upon visible light irradiation at $37^{\circ} \mathrm{C}$ of $M$. hominis (O), $A$. laidlawii $+\mathbf{S}(\boldsymbol{\square})$ and $A$. laidlawii $-\mathbf{S}(\boldsymbol{\Lambda})$ in the exponential phase of growth, in the presence of $0 \cdot 1 \mu \mathrm{g} \mathrm{HP} \mathrm{ml}^{-1}$. The cells (initial concentrations as for Fig. 3) had been previously incubated with HP for $60 \mathrm{~min}$ in the dark at room temperature. Each point represents the mean of four independent experiments performed in duplicate. The largest standard error obtained [log (c.f.u. $\mathrm{ml}^{-1}$ )] was $0 \cdot 2$.

The effect of HP plus visible light treatment on membrane proteins was examined by SDS polyacrylamide gel electrophoresis. Increasing illumination time gave a progressive accumulation of high molecular weight complexes on the stacking gel, with a concomitant disappearance of the normal protein bands from the separating gel. This result was obtained with both mycoplasma strains in both phases of growth. Nevertheless, there was a slight difference between the electrophoretic patterns obtained with $A$. laidlawii $+\mathrm{S}$ (Fig. 5) and with $A$. laidlawii-S (Fig. 6). In particular, the dark treatment of $A$. laidlawii $+\mathrm{S}$ cells with HP caused a decrease in intensity of some protein bands (Fig. 5, lane D); this phenomenon was enhanced after $30 \mathrm{~s}$ illumination (Fig. 5, lane E). With increasing illumination time, many protein bands gradually disappeared; after irradiation times as long as 10-30 min only two bands were present (Fig. 5, lanes I-K). In contrast, for $\boldsymbol{A}$. laidlawii-S, control and dark-treated cells yielded the same electrophoretic pattern, and the decrease and/or disappearance of some protein bands (Fig. 6) was slower than that observed for $A$. laidlawii $+\mathrm{S}$.

Electron microscopic examination of cells treated for $90 \mathrm{~min}$ in the dark with HP concentrations in the range $0 \cdot 1-100 \mu \mathrm{g} \mathrm{ml}^{-1}$ indicated a slight increase in the volume of $\boldsymbol{A}$. laidlawii $(+\mathrm{S}$ and $-\mathrm{S})$ cells. However, no significant ultrastructural modifications were observed for similarly dark-treated $M$. hominis cells. Upon illumination, HP-loaded $A$. laidlawii cells became swollen, with a decreased electron density; a few lysed cells were also observed after prolonged illumination. Irradiation of HP-loaded $M$. hominis cells induced a progressive loss of typical morphology, accompanied by rounding and a decrease in electron density.

The content of cholesterol in $M$. hominis, $A$. laidlawii $+\mathrm{S}$ and $A$. laidlawii $-\mathrm{S}$ was 80,15 and $0 \cdot 8 \mu \mathrm{g}$ (mg total protein) ${ }^{-1}$, respectively. 


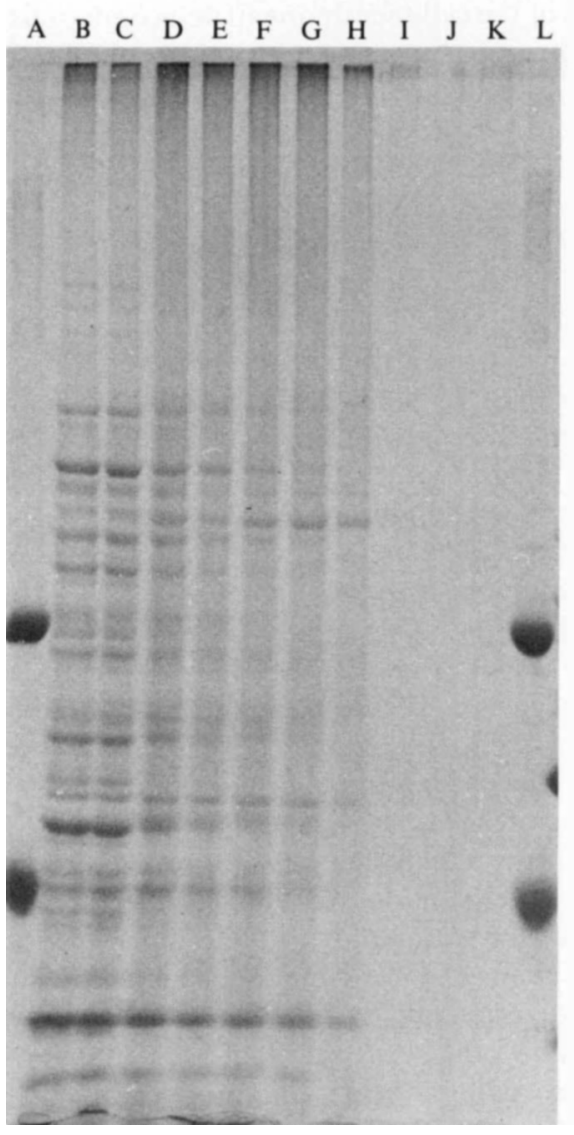

Fig. 5

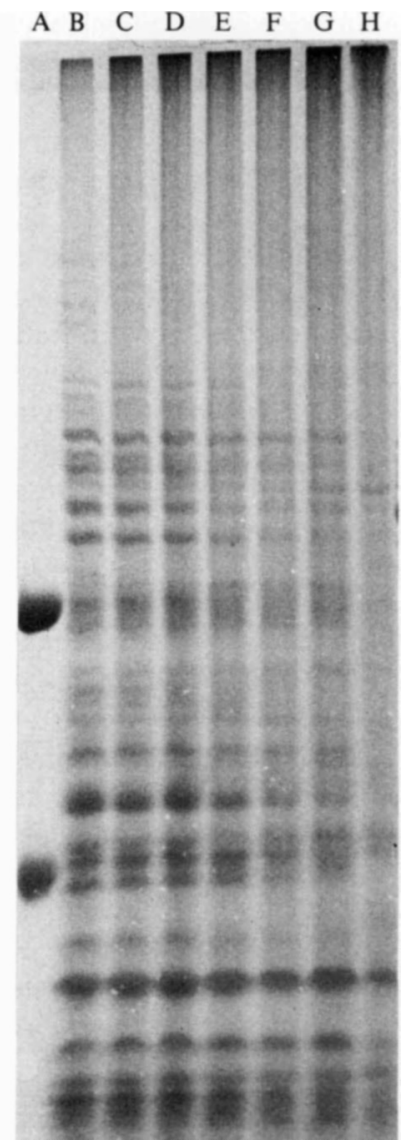

Fig. 6

Fig. 5. Photodynamic effect of HP on membrane proteins of $A$. laidlawii $+\mathrm{S}$ in the stationary phase of growth. A and L, molecular weight markers: bovine serum albumin (67000) and ovalbumin (43000). B, cells untreated with HP and unirradiated; C, cells irradiated $(30 \mathrm{~min})$ in the absence of HP; D, cells treated with $\mathrm{HP}\left(0 \cdot 1 \mu \mathrm{g} \mathrm{ml}^{-1}\right)$ in the dark. E-K, cells irradiated for various times in the presence of $\mathrm{HP}$ $\left(0 \cdot 1 \mu \mathrm{g} \mathrm{ml}^{-1}\right)$ : E, $30 \mathrm{~s} ; \mathrm{F}, 1 \mathrm{~min} ; \mathrm{G}, 2 \mathrm{~min} ; \mathrm{H}, 4 \mathrm{~min} ; \mathrm{I}, 10 \mathrm{~min} ; \mathrm{J}, 20 \mathrm{~min}: \mathrm{K}, 30 \mathrm{~min}$.

Fig. 6. Photodynamic effect of HP on membrane proteins of $A$. laidla $w^{\prime} i-\mathrm{S}$ in the exponential phase of growth. A, molecular weight markers (same as Fig. 5). B, cells irradiated ( $30 \mathrm{~min}$ ) in the absence of HP; C, cells treated with HP $\left(0 \cdot 1 \mu \mathrm{g} \mathrm{ml}^{-1}\right)$ in the dark. D-H, cells irradiated for various times in the presence of $\mathrm{HP}\left(0 \cdot 1 \mu \mathrm{g} \mathrm{ml}^{-1}\right)$ : D, $30 \mathrm{~s} ; \mathrm{E}, 1 \mathrm{~min} ; \mathrm{F}, 2 \mathrm{~min} ; \mathrm{G}, 4 \mathrm{~min} ; \mathrm{H}, 10 \mathrm{~min}$.

\section{DISCUSSION}

Two lines of evidence indicate that the interaction of HP with Mollicutes differs from that with bacterial cells (Bertoloni et al., 1984). Thus, under our experimental conditions, the amount of HP firmly bound to $M$. hominis and $A$. laidlawii steadily increased with increasing porphyrin concentration in the incubation medium, at least up to $100 \mu \mathrm{g} \mathrm{ml}^{-1}$; with bacterial cells, the intracellular dye concentration reached a maximum at about $30 \mu \mathrm{g} \mathrm{ml}^{-1}$ (Bertoloni et al., 1984). Moreover, Mollicutes cells in the exponential (but not in the stationary) phase of growth were sensitive to HP-induced dark toxicity, which again contrasts with the behaviour of both Grampositive and Gram-negative bacterial cells. Since in all cases, porphyrin preferentially interacts with the cytoplasmic membrane, the above-mentioned differences may reflect differences in chemical composition and/or accessibility of cell membranes between Mollicutes and walled bacteria. 
The importance of the chemical composition of the cell membrane in determining its binding capacity for HP is also suggested by the differences in the amounts of cell-bound HP observed between $M$. hominis, A. laidlawii $+\mathrm{S}$ and $A$. laidlawii $-\mathrm{S}$ (see Fig. 2). It is worth emphasizing that mycoplasmas are unable to promote cholesterol synthesis, hence they require exogenous cholesterol donors. However, acholeplasmas do not require cholesterol for growth and, in particular, A. laidlawii-S, being cultured in serum-free medium, is almost devoid of cholesterol. For these reasons the $M$. hominis cell membrane has a higher sterol content than that of $A$. laidlawii, as shown by our total cholesterol determinations. Therefore, our results might indicate a role for sterols in the cell membrane in determining the extent of HP binding by $M$. hominis, $A$. laidlawii $+\mathrm{S}$ and $A$. laidlawii-S. Sterols appear to play a role also in modulating the photosensitivity of Mollicutes. M. hominis is more photosensitive than A. laidlawii, in spite of its lower amount of cell-bound porphyrin. This may indicate that sterols are involved in the HP-induced photodamage at the level of cell membrane. Thus, sterols act as stabilizers of membrane architecture: this behaviour is exemplified by the shoulder observed in the survival curves of $M$. hominis and $A$. laidlawii $+\mathrm{S}$ at short irradiation times. The importance of lipid peroxidation, and in particular the formation of cholesterol-related hydroperoxides, in causing the lysis of model cell membrane and erythrocytes has been invoked by previous authors (Lamola et al., 1973). The lower sensitivity of acholeplasma cells, in particular $A$. laidlawii $-\mathrm{S}$, to the photosensitizing action of HP could be due, in part, to the presence of carotenoids in the neutral lipid phase, as previously observed by Cooney \& Krinsky (1972) and Rottem et al. (1968) with other photosensitizers. Carotenoids are known to be efficient inhibitors of porphyrin photosensitization by quenching some photogenerated oxygen derivatives, including ${ }^{1} \mathrm{O}_{2}$ (Spikes, 1982).

An alternative mechanism of cytolysis involves the formation of protein-protein crosslinkages as a result of dark reactions between photo-oxidation products of specific amino acid residues (Girotti, 1980; Verweij et al., 1981). The formation of high-molecular-weight covalent adducts between membrane proteins is also demonstrated by our electrophoretic studies on irradiated $M$. hominis and $A$. laidlawii cells. However, examination of the data obtained by SDSgel electrophoresis and electron microscopy shows that cross-linking of membrane proteins precedes cell lysis. In the light of recently published observations on porphyrin-photosensitization of yeast cells (Ito \& Ito, 1984), it is likely that both reaction pathways operate simultaneously and the prevalence of either mechanism is determined by a variety of factors, including the aggregation state of the porphyrin (which in turn affects the subcellular distribution of the dye) and the chemical composition of the cell membrane.

In conclusion, all the available data indicate a major role for the cell membrane in HP binding and HP photosensitization of Mollicutes cells.

This work was supported in part by grant no. 84.00630 .44 from Consiglio Nazionale delle Ricerche, Progetto Finalizzato Oncologia. We wish to thank Mr M. Guida for secretarial assistance.

\section{REFERENCES}

Bertoloni, G., Dall'Acqua, M., Vazzoler, M., Salvato, B. \& JoRI, G. (1982). Photosensitizing action of hematoporphyrin on some bacterial strains. Médecine, Biologie et Environnement 10, 239 242.

Bertoloni, G., Salvato, B., Dall'Acqua, M., VazZOLER, M. \& JORI, G. (1984). Hematoporphyrinsensitized photoinactivation of Streptococcus faecalis. Photochemistry and Photobiology 39, 811-816.

Bligh, E. G. \& DYER, W. J. (1959). A rapid method of total lipid extraction and purification. Canadian Journal of Biochemistry and Physiology 37, 911-917.

CoONEY, J. J. \& KRINSKY, N. I. (1972). Photodynamic killing of Acholeplasma laidlawii. Photochemistry and Photobiology 16, 523-526.

Daniels, M. J. \& Meddins, B. M. (1973). Polyacrylamide gel electrophoresis of mycoplasma proteins in sodium dodecyl sulphate. Journal of General Microbiology 76, 239-242.

GirotTI, A. W. (1980). Photosensitized cross-linking of erythrocyte membrane proteins. Biochimica et biophysica acta $602,45-56$.

ITO, T. \& ITo, A. (1984). Enhancement of porphyrinphotosensitization of yeast cells by ethanol. Photochemistry and Photobiology 40, 429-434.

JoRI, G. \& SPIKES, J. D. (1981). Photosensitized oxidation in complex biological structures. In $O x y$ gen and Oxy-radicals in Chemistry and Biology, pp. 461-474. Edited by M. A. J. Rodgers \& E. I. Powers. New York: Academic Press.

JORI, G. \& SPIKES, J. D. (1984). Photobiochemistry of porphyrins. In Topics in Photomedicine, pp. 183318. Edited by K. C. Smith. New York: Plenum Press. 
JoRI, G., Reddi, E., Tomio, L., Salvato, B. \& Calzavara, F. (1979). Time dependence of hematoporphyrin distribution in selected tissue of normal rats and in ascites hepatoma. Tumori $\mathbf{6 5}, 425-452$.

Lamola, A. A., Yamane, T. \& Trozzolo, A. M (1973). Cholesterol hydroperoxide formation in red cell membranes and photohemolysis in erythropoietic protoporphyria. Science 179, 1131-1133.

Meloni, G. A., Bertoloni, G., Busolo, F. \& Conventi, L. (1980). Colony morphology, ultrastructure and morphogenesis in Mycoplasma hominis, Acholeplasma laidlawii and Ureaplasma urealyticum. Journal of General Microbiology 116, 435-443.

Modn, J. \& Christensen, T. (1981). Photodynamic effects on human cells exposed to light in the presence of hematoporphyrin. Localization of the active dye. Cancer Letters 11, 209-214.

RAZIN, S. (1963). Osmotic lysis of Mycoplasma. Journal of General Microbiology 33, 471-475.

RazIN, S. (1978). The mycoplasmas. Microbiological Reviews 42, 414-470.
Reynolds, E. W. (1963). The use of lead citrate at high $\mathrm{pH}$ as an electron-opaque stain in electron $\mathrm{mi}-$ croscopy. Journal of Cell Biology 17, 208-212.

RotTem, S. \& RAzIN, S. (1972). Isolation of mycoplasma membranes by digitonin. Journal of Bacteriology 110, 699-705.

RotTem, S., GotTFried, L. \& RAZIN, S. (1968). Carotenoids as protectors against photodynamic inactivation of the adenosine triphosphatase of Mycoplasma laidlawii membranes. Biochemical Journal 109, 707-708.

Rudel, L. L. \& MORRIS, M. D. (1973). Determination of cholesterol using $o$-phthalaldehyde. Journal of Lipid Research 14, 364-366.

SPIKES, J. D. (1982). Photodynamic reactions in photomedicine. In The Science of Photomedicine, pp. 113-135. Edited by J. D. Regan \& J. A. Parrish. New York \& London: Plenum Press.

VerweiJ, H., Dubbelman, T. M. A. R. \& VAN STEVENINCK, J. (1981). Photodynamic protein crosslinking. Biochimica et biophysica acta 647, 87-94. 